\title{
Women Knowledge and Legal Reality: Advancing the Frontier of Legal Education
}

\author{
By Grace Emmanuel Kaka*
}

\begin{abstract}
The inadequacy of the law on the rights of women led to the feminist movement whereby feminist theories were developed but are not part of legal education. Since legal education has long suffered the tension between the claims of what is proper for training for a profession, and the education or training of scholars in the academy, the students ought to learn the technical aspects of law, and the scope of legal education should focus primarily on teaching legal doctrine. The objective of this paper is to advocate that these feminist legal theories be inculcated to advance the frontier of legal education in our institutions so that the Law students will be able to make informed decisions on the nature of Law. The methodology used is the secondary source of data collection. The findings are that feminist ideas are not adequately addressed in legal education since it is not yet the practice to convey these ideas to law students in a systematic manner and law courses include an eclectic choice of feminist literature with no, or very little effort at explaining the significance of feminist critiques in the context of other (mainstream) legal literature. Therefore the study concludes that if these theories form part of law student's curriculum, the students will thereby learn how to take responsibility for their own views of the nature of law and systematic engagement with feminist critiques in legal education can enable law students to question the very foundations of mainstream knowledge.
\end{abstract}

Keywords: Feminism, knowledge, legal education, legal reality, women

\section{Introduction}

Legal knowledge is portrayed as objective and neutral, and despite there being extensive critiques on this view in the literatures, it still is the dominant paradigm in the teaching of law. Legal education has traditionally been a white male affair, to which women and people of colour have only recently gained entry. For many years, white male dominance of legal education was maintained through admission policies consciously designed to exclude women, members of disfavoured ethnic groups, and the economically disadvantaged. ${ }^{1}$ Within the last quarter century, the composition and complexion of law school student bodies have changed as historically underrepresented groups have been admitted to law school in greater numbers, chiefly as the beneficiaries of race and gender conscious admission programs. ${ }^{2}$ These race and gender conscious admissions programs, generally referred to as affirmative action" plans have always been controversial and have been the

\footnotetext{
${ }^{*}$ LL.M., Lecturer II, Faculty of Law, Misau Campus, Bauchi State University, Bauchi, Nigeria.

${ }^{1}$ Dowd, Nunn \& Pendagast (2003) 12.

${ }^{2}$ See Kidder (2003) 1171; Littlejohn \& Rubinowitz (1987).
} 
target of a growing number of court challenges, anti-affirmative action voter initiatives, and legislative and executive counter efforts. ${ }^{3}$

The legal status of this affirmative action in higher education admission programs was clarified by the US Supreme Court's decision in Grutter v. Bollinge ${ }^{4}$. This could not have been possible without the movement led by the women groups now called the feminist. This paper would deal with: legal education, history and scope of legal education, a brief definition of feminism, the historical development of feminist legal theories, the feminist legal theories that have been developed over the years, relevance of these theories to law students i.e. development of feminist legal methods, findings, recommendations and conclusion.

\section{Legal Education}

Legal education is the education of individuals who intend to become legal professionals or those who simply intend to use their law degree to some end, either related to law, politics or academics. The study includes first degrees in law, vocational courses e.g Nigerian Law School for Nigeria, applied legal education for specific branch of law such as Business aw, human resources and labour law, higher education degrees and doctorate courses. Legal education generally focuses either on pedagogy or substantive content. It ought to incorporate interdisciplinary analysis of law in order to change the very fundamentals of legal knowledge. ${ }^{5}$ Legal education must take as a starting point that we need to create useful capacities in our students. While there are many abstracted fields of study, from sociology and literatures to economics, which can help inform a capable understanding of law, law itself is an applied discipline involved in creation and operations of critical institutions through which humans order many of their most important social activities. ${ }^{6}$

\section{History and Scope of Legal Education}

Legal education has long suffered the tension between the claims of what is proper for training for a profession, and the education or training of scholars in the academy. ${ }^{7}$ In keeping with the professional connection of legal education, a persistent stream of thought is that effective learning in the profession amounts to good lawyering skills. In this view, the students ought to learn the technical aspects of law, and the scope of legal education should focus primarily on teaching legal doctrine. In common law countries, courts

\footnotetext{
${ }^{3}$ Kidder (2001) 1059-60

4 (2003) 123 S. Ct. 2325

${ }^{5}$ Parashar (2000) 59.

${ }^{6}$ Goodenough (2013) 847-848.

${ }^{7}$ Pirie (1987) 576. See also Sunstein (1995) 267.
} 
function as the interpreters of the uncodified common law (as well as of statutes) and are the primary source of legal doctrine. For a long time, lawyers were primarily trained to read and interpret case law, and this training was in the form of apprenticeship at the Inns of Courts in London. ${ }^{8}$ However, under the influence of continental systems legal education was eventually made part of the academy, but tension remained about the content of this discipline. ${ }^{9}$

\section{History}

Historically, legal education, even in the universities, has focused on legal doctrine available by the study of case books - a compilation of relevant cases on a specific area like criminal law or contracts. In the case method, the methodology of teaching may have changed but the content still is predominantly legal doctrine. ${ }^{10}$ It is of course true that in Commonwealth countries many contemporary law schools and universities have sought to broaden the framework of legal education by emphasizing sociological or historical or other aspects of law. But systematic attempts at presenting law programs with specifically interdisciplinary bases have not proliferated. Part of the reason for this narrow focus of legal education may be the control exercised by professional bodies on legal curricula. Carrie Menkel Meadow argues, legal education understood as a compromise between theory and vocational practice is based on a misconceived idea that one cannot simultaneously learn the theory of law and learn to practice law, or that attempting to do so is counterproductive. ${ }^{11}$ There are at least two counter arguments against restricting the focus of legal education to merely professional training: that not everyone will become a solicitor, and that even practising lawyers need wider education. In contemporary societies knowledge of law is relevant not only in 'lawyering' but in a wide range of areas. It is commonly said that less than half of law students even plan to become practicing lawyers. Therefore legal education ought not to be merely technical in its scope. This is a reasonable enough argument for broadening the scope of legal education but Parashar ${ }^{12}$ opines that it is unnecessarily restrictive, as it concedes that professional lawyers can get by with technical training only. There is increasing recognition of the need to make professional education much wider and Schon argues that all kinds of knowledge, rather than only codified, propositional knowledge, are necessary for good professional performance. ${ }^{13}$ Therefore, the scope of legal education has to be broader than just training lawyers in technical aspects of legal doctrine.

\footnotetext{
${ }^{8}$ Twining (1994); see also Kavanagh (1989) 11.

${ }^{9}$ Carrington (1990) 527; Carrington (1995) 691.

${ }^{10}$ Steven (1983) 66.

${ }^{11}$ Meadow (1985) 676 and 685, and Meadow (1994) 593

${ }^{12}$ Parashar (2000) $60-61$.

${ }^{13}$ Schon (1983); see also Eraut (1992) 98.
} 
Those who argue for legal education to primarily focus on skills training unfortunately conceptualise training very narrowly and, therefore, do not even serve well the interests of the profession. ${ }^{14}$ For someone to be only a competent practitioner (and nothing more) it is still necessary to have critical judgment, capacity to analyse, relate one's own position to others' opinions. Therefore, even for lawyers it is important to emphasise that their everyday activities of interpreting laws have wider implications and influences. The apparent tension between intellectual goals and technical professional training overlooks the fact that the generation of critical abilities, while an intrinsic essence of education, also has practical benefits as lawyers with such abilities can assist in bringing about changes through reinterpretations of law, as well as accomplish change in the case of individual clients who are not served well by current practices or solutions. ${ }^{15}$ Thus, how to determine what may be relevant information, and to research and access such information, and the skill to construct new arguments are the more enduring and invaluable skills required to advance the frontier of legal education.

Within legal education discourse, it is not universally accepted that law students need to develop their critical skills in an interdisciplinary a manner. However, it is argue that adequate legal education can only ever be achieved through an interdisciplinary study of law, and that deep learning in law must be interpreted to mean that students learn how legal knowledge is constructed and defined in the wider context of society. ${ }^{16}$ Debates continue as to whether legal scholars can be truly interdisciplinary because they are caught in the paradigm of their discipline and as a result, legal analysts have never thrown up questions about law as sociologists have done. ${ }^{17}$ In contrast, Kalman is of the view that academic lawyers need not remotely resemble historians, economists, literary theorists or philosophers. ${ }^{18}$ In a similar vein, arguments are raised as to whether the sociology of law is a legal or social science subject, ${ }^{19}$ or whether interdisciplinary studies of law will only be successful if they address the professional mission of legal education, including the training of lawyers. ${ }^{20}$ These disagreements do not detract from the fact that major challenges to the doctrinal focus of legal analyses have been presented by the critical legal studies, feminist and other interdisciplinary movements. Very briefly, these critiques in various forms challenge the claim that law is autonomous, objective, neutral or principled. ${ }^{21}$ But not much of this literature gets translated

\footnotetext{
${ }^{14}$ Parashar (2000) 61-62.

${ }^{15}$ Report by The Consultative Group On Research And Education, In Law, Law And Learning: Report To The Social Sciences And Humanities Research Council Of Canada, 1983 at 49.

${ }^{16}$ Ibid.

${ }^{17}$ Murphy \& Roberts (1987) 683

${ }^{18}$ Kalman (1996) 1005.

${ }^{19}$ Black (1989) 765. See also Fielding \& Fielding (1983) 181.

${ }^{20}$ Ernst (1996) 979. See also Twining (1997) 198-221 where he argues that the scope of legal education should be more than a study of appellate court judgments but still remains focused on the process of adjudication and all he wants is to look at the disputed questions of fact, to pre-trial and post-trial events. He thus restricts legal inquiry to the process of adjudication.

${ }^{21}$ Hunt (1987); Tushnet (1991) 1515.
} 
into teaching programs in any systematic manner. Why is this so? A possible reason is that legal education scholarship and critiques of legal knowledge do not sufficiently interconnect. ${ }^{22}$ It is worthy of note that, there is ample legal scholarship on various aspects of legal education. But a systematic connection between pedagogy and substance must become the focus of analysis.

What it is that the students should learn can, and often does, get left out of consideration? At the same time, the Socratic Method can also result in classroom dynamics that are intimidating to some. It can thus establish hierarchies which silence women. Extensive evidence now exists that many women do not feel comfortable with the combative style of the Socratic Method and remain silent in the classroom. ${ }^{23}$ Various feminist critiques of law rely on interdisciplinary analyses to show the embeddedness of law in the prevailing economic, political and sociological paradigms, and how law helps in maintaining hierarchies of wider society. But such ideas cannot be effectively communicated in such an atmosphere. Therefore, teaching methodologies must shift the focus from teachers as the authoritative knower's of law, as well as simultaneously incorporate a broader range of substantive content - and not only in feminist classrooms.

\section{Feminism}

It is the belief in the social, political, and economic equality of the sexes. The movement is organised around this belief by the women folk. It is also said to be an analysis of women's subordination for the purpose of fighting out how to change it. Feminist Theory is an outgrowth of the general movement to empower women worldwide. Feminism can be defined as a recognition and critique of male supremacy combined with efforts to change it. ${ }^{24}$ It can also be defined as the quest by the female folk to gain respect, relevance and acceptability in the men's world. The goals of feminism are: to demonstrate the importance of women; to reveal that historically women have been subordinate to men and to bring about gender equity. Simply put: feminists fight for the equality of women and argue that women should share equally in society's opportunities and scares resources. ${ }^{25}$

\section{Development of Feminist Legal Theories}

During the century preceding the 1960s, there had been substantial efforts to change the law respecting women's rights in the United States. The women's

\footnotetext{
${ }^{22}$ Goldring (1996) 125.

${ }^{23}$ Guinier et al (1994) 1; Dusky (1996) 13-14; Thornton (1996) 78. See Davies (1996).

${ }^{24}$ Gordon (1986) 20-30 ("I favour a definition of "feminist" that allows men, as well as women, to make this choice"). Some feminists disagree". See also Mackinnon (1989) 55-57 (noting that men can be feminised by experiences such as rape, but that such identifications with women are temporary and unusual).

${ }^{25}$ Fineman (1985).
} 
suffrage movement fought for inclusion of sex in the text of the Fourteenth Amendment; Myra Bradwell fought for right to be admitted to the bar under the Privileges and Immunities Clause of the Fourteenth Amendment; many litigants and lawyers sensitive to issues of sex discrimination raised legal issues concerning women's equality; and a major and finally successful effort to pass the Nineteenth Amendment to the Constitution gave women the right to vote. ${ }^{26}$ In the 1960s, a ""second wave" of an active women's rights movement developed from the civil rights struggle, leading to renewed efforts both to change the law so as to abolish sex discrimination and to reshape the legal profession so as to integrate women within $1 \mathrm{lt}^{27}$ This effort, led by a new generation of women's rights attorneys, manifested the interrelationship of theory and practice. Ruth Bader Ginsburg (then a law professor and counsel to the ACLU Women's Rights Project), important scholars in the area of sex discrimination such as Herma Hill Kay at Boalt Hall and Barbara Babcock at Stanford (who taught one of the first Women and the Law courses at Yale Law School), and many others taught and influenced a younger generation of students who would become the leading lawyers handling sex discrimination litigation. For example, the women's rights litigators who founded the San Francisco public interest firm Equal Rights Advocates in 1974 (Wendy Williams, Mary Dunlap, and Nancy Davis) had worked with Herma Hill Kay at Boalt Hall. ${ }^{28}$ Ann Freedman and others who formed the Women's Law Centre in Philadelphia had been students at Yale who worked with Barbara Babcock. ${ }^{29}$ The National Conference on Women and the Law, an annual meeting of practitioners, law students, and law teachers also played a critical role in providing a national forum to discuss and generate cutting-edge work in the area of women's rights. ${ }^{30}$ Radical ideas about topics such as sexual harassment, date rape, battered women, and self-defence were discussed for the first time in these fora by lawyers who were working on these issues nationwide. The litigation efforts that followed, which posed issues of equal protection in a host of areas such as social security, ${ }^{31}$ a pregnancy discrimination, and parental leave, ${ }^{32}$ as well as activist efforts around the Equal Rights Amendment ${ }^{33}$ raised

\footnotetext{
${ }^{26}$ Becker, Bowman \& Torrey (1994).

${ }^{27}$ Bowman \& Schneider (1998) 250.

${ }^{28}$ Fuchs Epstein (1993) 137-139. (Describing the founding of Equal Rights Advocates). For a recent discussion of the evolution of the work of Equal Rights Advocates, see Scales-Trent (1997).

29 Babcock et al (1975).

${ }^{30}$ Cain (1997) 371-381 (describing the importance of' the conference to the development of feminist legal theory and her experience as a participant, panellist, and organiser).

${ }^{31}$ Califano V. Webster (1977) 430 U.S. 313 (construing S. 215 of the Social Security Act); Califano V. Goldfarb (1977) 430 U. S.199 (construing the Federal Old-Age, Survivors and Disability Insurance Program).

${ }^{32}$ California Federal Sav. \& Loan Ass'n v. Guerra, (1987) 479 U.S. 272 (construing the Pregnancy Discrimination Act of 1978); Geduldig v. Aiello, (1974) 417 U.S. 484; (construing section 2626 of the California Unemployment insurance Code).

${ }^{33}$ Emerson et al (1971) 871 (Outlining the development, structure, and anticipated operation of the proposed Equal Rights Amendment).
} 
important arguments about the nature of gender which laid the foundation for feminist legal theory. Although the presence of women teachers in the law schools had a huge impact in mobilizing, energizing and supporting a younger generation of women entering the legal profession to do this work, the theories of equality and the Federal Equal Rights Amendment emerged primarily from the practical demands of activist efforts at lawmaking. For example, in 1971, Barbara Brown, Ann Freedman, Tom Emerson, and Gail Falk wrote an important article on Constitutional equality specifically to shape Congressional efforts to pass the Amendment. Catharine MacKinnon's 1979 book, Sexual Harassment of Working Women, was written to present a legal theory that explained the harm of sexual harassment as it had already been litigated by many feminist lawyers and provide an effective remedy for these harms. ${ }^{34}$ In Nigeria for instance, the issue of the traditional African notion of the woman being a mere object of scorn has only been minimised but not clearly eradicated because of the existence of the Private domain which has dominate the thinking of the elites.

\section{Feminist Legal Theories}

Feminist legal theories are about analysing the world more adequately than Mainstream theory. They are at the same time about enabling a world with more equitable sex/gender relations. In this sense they are self-consciously political though the politics they advocate vary. They are not only about advancing some group called women but also interrogating the power to specify insiders-outsiders, movement agendas, and even the progressiveness of theory and practice that claim to be feminist. ${ }^{35}$ Today, feminist legal theories have evolved into four major schools. They are:

- Formal equality theory

- Cultural feminism

- Dominance theory and

- Post-modern or anti-essentialist theory

\section{Formal Equality Theory}

Formal equality theory is grounded in liberal democratic thought. It argues that women should be treated the same way as men. ${ }^{36}$

\section{Cultural Feminism}

It deals with the need to take account of the differences that exist between men and women.

\footnotetext{
${ }^{34}$ MacKinnon (1979).

${ }^{35}$ Bowman \& Schneider (1998) 253.

${ }^{36}$ Ibid
} 
The emergence of its perspectives in the law was largely shaped by efforts to understand the uniquely female experiences of pregnancy and motherhood. For instance, the failure of the Supreme Court's equality jurisprudence to address issues of pregnancy as implicating issues of gender equality ${ }^{37}$ had an enormous impact on the lives of women and the law. The Pregnancy Discrimination Act of 1978 came as a response to these issues. This Act under Title VII $^{38}$ defined pregnancy discrimination as sex discrimination. It also generated renewed attention to the notion of "difference" in a variety of contexts.

\section{Dominance Theory}

Dominance theory sidesteps both formal equality and cultural feminism approaches. It focuses instead upon the embedded structures of power that makes man's characteristics the norm from which "difference" is constructed. It presented an important theoretical framework within which to understand the harms of violence against women in areas such as domestic violence, rape, sexual harassment, and pornography. Formal equality theory was inadequate to analyse these harms experienced almost exclusively by women, because it failed to address the patriarchal structures of power that led to and perpetuated them. ${ }^{39}$ Dominance theory emerged from efforts to grapple with the reality and experiences of male dominance and privilege in these areas.

\section{Post-modern or Anti-essentialism Theory}

Anti-essentialism or Post-modern, by contrast, contends that there is no single category "female," It points instead to the varying perspectives resulting for example, from the intersection of gender, race and class. It developed from challenges to a notion of a single feminist legal theory and perspective and articulated the need to account for the wide range of feminist perspectives that emerged from women of colour, issues of ethnicity, problems of immigrant women, and cultural differences. ${ }^{40}$ For example, Kimberle Crenshaw criticises feminist legal theory's failure to reflect African American women's experience of rape," while Paulette Caldwell explains how employment discrimination law

\footnotetext{
${ }^{37}$ See Geduldig, 417 U.S. at 497 no. 20 (stating that discrimination based upon pregnancy is not sex discrimination under the Equal Protection Clause, because it classifies between nonpregnant persons, who can be male or female, and pregnant persons).

38 (1994) 42 U.S.C. g 2000e(k).

${ }^{39}$ Bowman \& Schneider (1998) 252.

${ }^{40}$ Crenshaw (1989) 140 Thereinafter Crenshaw, DE marginalising the Intersection (arguing that many of the experiences that black Women face are not subsumed within the traditional boundaries of race or gender discrimination); Crenshaw (1991) 1241, 1242-44 (describing the intersectional location of 1vomen of colour and their marginalization Within dominant resistance discourses); Harris P. A., Race and essentialism in Feminist Legal Theory (42 Stan, L Rev., 1990) 581, 585(discussing the need for multiple consciousness in the feminist movement).
} 
fails to capture discrimination that is motivated by both sex and race. ${ }^{41}$ This approach has emphasised the importance of storytelling both as a way to bring diverse experiences into the Law and as a way to broaden the legal descriptions of experience that are translated into law. ${ }^{42}$ This theoretical perspective challenges us to address the intersections of race, gender, ethnicity, class, sexual orientation, age, and disability, as well as to explore what commonality might mean in coalition efforts. It also challenges us to move beyond the telling of stories to more substantive change.

\section{Relevance of Feminist Theories to Law Students}

Because feminism as a discipline that focuses on the significance of gender and the societal inequality resulting from values and assumptions based on gender, feminist scholars are found in all disciplines. As a group, feminists are concerned with the implications of historic and contemporary exploitation of women within society, seeking the empowerment of women and the transformation of institutions dominated by men. In addition, many feminists also use distinctive feminist methods to bring women's experiences to the foreground, such as consciousness raising or storytelling. ${ }^{43}$ Such methods recognise the validity and importance of women's experiences and ground feminist theory and research.

One important characteristic of feminism is that it represents the integration of practice and theory. As noted by historian Linda Gordon, feminism is "an analysis of women's subordination for the purpose of figuring out how to change it. ${ }^{44}$ The recognised desirability of this practical aspect has made many feminists gravitate toward law and legal reform as objects of study and action. They have had many successes within law. In fact, it is fair to state that feminism, along with economics and, to some extent, psychology, has had a visible and immediate impact on law over the past several decades.

The effect is apparent not only in the academic and in legal scholarship, but in the doctrine employed by courts and developed by legislative bodies. ${ }^{45}$ The very institutions of law have been assessed and, occasionally, revised in the light of feminist insights and arguments. The fact that feminism has had an impact is not surprising given the huge influx of women into law schools beginning in the 1970s. ${ }^{46}$ While there were women in law schools prior to this period, their numbers have increased significantly during this time. Further,

\footnotetext{
${ }^{41}$ Caldwell (1991) 371-72.

42 Delgado (1989) 2412-2413 (describing how outsiders' stories build cohesion within the excluded group and subvert the dominant ideology); Lane (1989) 2083-84 (describing the broadening of legal discourse to include the stories of "outsiders" such as women and people of colour).

${ }^{43}$ Chamallas (2013) (noting that feminist legal theorists frequently use narratives of battered women in researching domestic violence).

${ }^{44}$ Gordon (1979).

${ }^{45}$ Carroll (1994) 12-13(noting the impact women in public office are having on public policies).

${ }^{46}$ American Bar Association (1998).
} 
women have been integrated into the profession at all levels. ${ }^{47}$ In the first wave of women to attend law school, many were explicitly interested in a feminist political agenda. They came to law schools with the mantra that "the personal is the political" ringing resolutely in their ears. ${ }^{48}$ They were interested in reform and the role that law would play in the project of engineering a more gender-equal society.

These early feminists were optimistic about using law to attain gender equality. The strategies of early legal feminist reformers were varied and their perspectives were not always compatible. One basic divide that emerged early in the articulation of a legal approach to feminist theory is still significant today - the issue of gender difference. What were the differences between women and men? How were they to be addressed? The majority of early feminist legal theorists adopted a discrimination model to the issue of gender. Their objective was to outlaw biased treatment and provide laws that allowed women equal opportunities with men. ${ }^{49}$ Other feminist scholars, however, wanted to develop and build upon the concept of gender difference. ${ }^{50}$ Gender inequality was not only produced and maintained through exclusion from or discriminatory treatment within existing social structures. Facially neutral rules could also generate inequalities, particularly since women's and men's societal circumstances were so different. Such differences demand different treatment mere formal equal treatment could not sufficiently address existing structural and ideological inequalities. This strand of feminism sought to question the legitimacy of existing gender norms and their implications for society's institutions and legal structures. The objective was not necessarily to eradicate these norms (a monumental task that has only begun), but to address the implications of gendered institutions. Institutions, including law were not perceived as neutral and potentially helpful in this regard. They were part of the problem as currently constructed. The feminist also project a methodology for its study. Thus Feminists have developed extensive critiques of law ${ }^{51}$ and proposals for legal reform. Feminists have had much less to say, however, about what the "doing" of law should entail and what truth status to give to the legal claims that follow. These methodological issues matter because methods shape one's view of the possibilities for legal practice and reform. Method organises the apprehension of truth; it determines what counts as evidence and

\footnotetext{
47 Ibid, at 4 (showing that women have participated in the legal profession in a variety of positions, including as judges, practicing attorneys, and professors).

48 Mackinnon (1989) (reasoning that "since a woman's problems are not hers individually but those of women as a whole, they cannot be addressed except as a whole. In this analysis of gender as a non-natural characteristic of a division of power in society, the personal becomes the political").

49 Reed v. Reed, (1971) 404 U.S. 71, 76 (holding that the Equal Protection Clause of the Fourteenth Amendment forbids states to give "mandatory preference" to a man over a woman as executor of an estate).

50 Mackinnon (1989) at 101 (stating that the "differences" approach does not "prohibit all differentiations between the sexes, but only those that are . . inaccurate or over generalized distinctions between the sexes").

${ }^{51}$ Freedman (1983); Harris (1990) ; Kay (1985) ; Law (1984) 955; Littleton (1997).
} 
defines what is taken as verification. ${ }^{52}$ Feminists cannot ignore method, because if they seek to challenge existing structures of power with the same methods that have defined what counts within those structures, they may instead "recreate the illegitimate power structures [that they are] trying to identify and undermine. ${ }^{53}$ Method matters also because without an understanding of feminist methods, feminist claims in the law will not be perceived as legitimate or "correct. It is suspected that many who dismiss feminism as trivial or inconsequential misunderstand it. ${ }^{54}$ Feminists have tended to focus on defending their various substantive positions or political agendas, even among themselves. Greater attention to issues of method may help to anchor these defences, to explain why feminist agendas often appear so radical (or not radical enough), and even to establish some common ground among feminists.

\section{Findings}

The Berkeley Women's Law Journal ${ }^{55}$ has been a leader in the struggle taking place in the academy to make sex, gender, race, and sexual orientation a part of the law school curriculum. This movement has been fuelled primarily by students and a number of law professors, many of whom are members of the Society of American Law Teachers. These members of the legal academy recognise the relevance and importance of issues relating to sex, gender, and sexual orientation, not only to our lives but also to our teaching and learning.

Good innovations have come from this effort, including new classes, casebooks, and scholarship on subjects like sex discrimination and the law, and gender roles and the law. ${ }^{56}$

An increased acceptance of these issues in some classrooms and institutions has resulted as well. Unfortunately, the response within the legal academy to this drive to recognise issues of sex, gender, and sexual orientation has not been wholly positive. The downside is marked by law professors who sex and gender their classroom hypotheticals and final exams.

In legal education in some countries like Australia, Nigeria etc, feminist critiques are at best considered the special interests of some academics (usually women) and it is left up to them to teach about feminist theories of law.

Feminist ideas are not adequately addressed in legal education since it is not yet the practice to convey these ideas to law students in a systematic manner and law courses include an eclectic choice of feminist literature with no or very little effort at explaining the significance of feminist critiques in the context of other (mainstream) legal literature.

\footnotetext{
${ }^{52}$ Bartlett (1990) $830-832$

53 Singer (1989).

${ }^{54}$ Bartlett (1990) 831.

${ }^{55}$ Wildman (1995) .

${ }^{56}$ Ibid
} 


\section{Recommendations}

Understanding should be inculcated more than mere inclusion of sex, gender, and sexual orientation in the law school curriculum at whatever level of law education.

Just as importantly, good law schools or institutions should address questions of what "justice" and "the rule of law" require, since these are the ultimate goals of a good legal system. They should be part of the analysis whenever novel legal issues are presented for resolution, and a motivating force in legal reforms. Of course, the meaning of "justice" or "the rule of law" can be complicated and debatable. But discussing and debating these ideas should be part of legal education. Indeed, legal educators should encourage law students to use their professional skills to contribute to the good of society. If legal professionals do not feel a responsibility to contribute to the rule of law and to promote justice, who will? And since lawyers are deeply enmeshed in the complex real world and are not immune to its temptations, particularly when the stakes are high, the best legal education should prepare students to act ethically, and think about difficult ethical and moral challenges such as the feminist legal theories that have evolved over the years.

If these theories form part of law student's curriculum, the students will thereby learn how to take responsibility for their own views of the nature of law and systematic engagement with feminist critiques in legal education can enable law students to question the very foundations of mainstream knowledge.

\section{Conclusion}

The law is an essential tool for advancing women's rights and gender equality. When a society is governed by the rule of law, with an accessible and just legal system, women can thrive, contribute to the system and improve it for future generations. The rule of law requires that laws are free from bias and discrimination "equally enforced and independently adjudicated, and consistent with international human rights norms and standards". As such, a robust and effective legal system based on the rule of law is central to assisting women to become equal partners in decision-making and development. This can therefore be achieved when legal education is broaden to include other areas such as sociology, psychology, economics, feminism, etc provided also that both theory and practice would be inculcated into the law student curriculum. Thus, sex, gender and sexual orientation are in the room whether we make them explicit or not, but everyone pretends that they are not noticing and in fact when they do, they tagged it 'women affair" or better still 'unscrupulous ladies affairs. But when feminist legal theories are well understood, the bias and discrimination perpetuated by law strictly so called would be understood and some amendments would be made to address the issues. 


\section{References}

American Bar Association (1998). "Facts about women and the law". Available at http://www.abanet.org/media/factbooks/womenlaw.pdf - accessed 11 May, 2015.

Babcock, B.A, Freedman, A.E., Norton, E.H. \& Ross, S.C. (1975). Sex discrimination and the law: Causes and remedies. Boston: Little, Brown.

Bartlett, K.T. (1990). "Feminist legal method", in Harvard Law Review 103(4):829888.

Becker, M., Bowman, C.G. \& Torrey, M. (1994). "Feminist jurisprudence: Taking women seriously" in Women Law Journal 80(3): 926.

Black, D. (1989). Sociological justice. Oxford University Press.

Bowman, C.G. \& Schneider, E.M. (1998). "Feminist legal theory, feminist lawmaking and the legal profession" in Fordham Law Review 67(2): 249-271.

Cain, P.A. (1997). "The future of feminist legal theory" in Wisconsin Women's Law Journal 11:367-383.

Caldwell, M.P. (1991). "A hair piece' perspectives on the intersection of race and gender" in Duke Law Journal (1991):365-396.

Carrington, P.D. (1990). "The revolutionary idea of University legal education", William and Mary Law Review 31(3):527-574.

Carrington, P.D. (1995). "Hail! Langdell” in Law and Social Inquiry 20: 691-760.

Carroll, S.J. (1994). "The politics of difference: Women public officials as agents of change" in Stanford Law and Policy Review 5(11):11-32.

Chamallas, M. (2013). Introduction to Feminist Legal Theory, $3^{\text {rd }}$ ed. NewYork: Wolters Kluwer

Crenshaw, K.W. (1989). "Demarginalizing the intersection of race and sex: A black feminist critique of Antidiscrimination politics, feminist theory and Antiracist politics" University of Chicago Legal Forum (1989):140, 139-167.

Crenshaw, K.W. (1991). "Mapping the margins: identity politics, intersectionality and violence against women of colour" in Stanford Law Review 43:1241-1299.

Davies, M. (1996). Delimiting the law: Postmodernism and the politics of law. Pluto press.

Delgado, R. (1989). "Storytelling for oppositionist and others: A plea for narrative" in Michigan Law Review 87(8):2411-2441.

Dowd, N.E., Nunn, K.B. \& Pendagast, J.E. (2003). "Diversity matter: Race, gender and ethnicity in legal education", in University of Florida Journal of Law and Public Policy 15(1):12-42.

Dusky, L. (1996). Still unequal. The shameful truth about women and justice in America. $1^{\text {st }}$ edition, Crown Publishers.

Emerson, T.I., Brown, B.A., Falk, G. \& Freedman, A.E. (1971). "The equal rights amendment: A constitutional basis for equal rights for women" in Yale Law Journal 80(5):871-981.

Eraut, M. (1992). "Developing the knowledge base: A process perspective on professional education" in R. Barnett (ed.) Learning to Effect, pp. 98-118. Buckingham: SRHE/Open University Press.

Ernst, D. (1996). "The lost law professor: review of John Henry Schelegel, American legal realism and empirical social science" in Chapel Hill, University Of North Carolina Press, Law and Social Inquiry 21(4):967-979.

Fielding, N. \& Fielding, J. (1983). "Teaching the sociology of law: An empirical study" in Journal of Law and Society 10(2):181-200. 
Fineman, M.A. (1985). "Feminist Legal Theory" in American University Journal of Gender, Social Policy and the Law 13(1):13-23.

Freedman, A.E. (1983). "Sex equality, sex differences, and the supreme court" in Yale Law Journal 92(6):913-968.

Fuchs Epstein, C. (1993). Women in Law. $2^{\text {nd }}$ ed. Illinois: University of Illinois Press

Goldring, J. (1996). "Cultural cringe or lessons for Australian legal education" in Legal Education Review 7(1): 125.

Goodenough, O.R. (2013)."Developing an E-curriculum: Reflections on the Future of Legal Education and on the Importance of Digital Expertise" in Chicago - Kent law Review 88(3):847-848.

Gordon, L. (1979). The struggle for reproductive freedom: Three stages of feminism, in capitalist patriarchy and the case for socialist feminism. $1^{\text {st }}$ edition. Zillah R. Eisenstein.

Gordon, L. (1986). "What's new in women's history" in Lauretis T.D (ed) Feminist studies/critical studies. De Lauretis, Teresa ed. 20-30.

Guinier, L., Fine, M., Balin, J., Bartow, A. \& Lee, D.S. (1994). “Becoming gentleman: Women's experiences at one Ivy League Law School" in University Of Pennsylvania Law Review 143(1):1-110.

Harris, A.P. (1990). "Race and essentialism in feminist legal theory" in Stanford Law Review 42(3):581-616.

Hunt, A. (1987). "The critique of law: What is critical about critical legal studies" in Journal of Law and Society 14(1):5-19.

Kalman, L. (1996). "Garbage mouth. Law and Social Inquiry" in Journal of the American Bar Foundation 21(4):1001-1006.

Kavanagh, P. (1989). "Legal education and the functionalisation of the University" in Australian Journal of Law and Society 11(5):1988-1989.

Kay, H.H. (1985). "Models of equality" in University of Illinois Law Review 1(1):, 3988.

Kidder, W.C. (2001).” Does the LSAT mirror or magnify racial and ethnic differences in educational attainment?: A study of equally achieving "elite" college students" in Californian Law Review 89:1057-1066.

Kidder, W.C. (2003). "Silence, segregation and student activism at Boalt Hall" in Californian Law Review 91(4):1167-1181.

Lane, S. K. (1989). "Foreword: telling stories" in Michigan Law Review 87(8):20832084.

Law, S.A. (1984). "Rethinking sex and the constitution" in University Pennsylvania Law Review 132: 955-1040.

Littleton, C.A. (1997). "Reconstructing sexual equality" in Californian. Law Review 75(4): I279-1337.

Littlejohn, E.J. \& Rubinowitz, L.S. (1987). "Black enrollment in law schools: Forward to the past?" in Thurgood Marshall Law Review 12: 415, 433-444.

Makinnon, A.C. (1979). Sexual harassment of working women: A case of sexual discrimination. New Haven: Yale University Press.

Mackinnon, A. C. (1989). "Toward a feminist theory of the state" in Journal of Gender Social Policy and the Law 95:55-57.

Meadow, C.M. (1985). "Too little theory too little practice? Steven's Law School: Review Essay" in American Bar Foundation Research Journal, 675-690.

Meadow, C.M. (1994). "Narrowing the gap by narrowing the field: What's missing from the MacCrate report - of skills, legal science and being a human being" in Washington Law Review 69: 593. 
Murphy, W. \& Roberts, S. (1987). "An Anniversary preface" in Modern Law Review 50:673-683.

Parashar, A. (2000). "Teaching family law as feminist critique of law" in UNSW Law Journal 23(2):58-85.

Pirie, A.J. (1987)." Objectives in legal education: The case for systematic instructional design" in Journal of Legal Education 37(4):576-597

Sarat, A. (1989). "Donald black discovers legal realism: From pure science to policy science in the sociology of law" in Law and Social Inquiry 14(4): 765-785.

Scales-Trent, J. (1997). "Equal rights advocates: addressing the legal issues of women of color" in Berkeley Women's Law Journal 13: 39-66.

Schon, D.A. (1983). The reflective practitioner: How professionals think in action. $1^{\text {st }}$ edition, Basic Books Publisher.

Singer, J.W. (1989). "Should lawyers care about philosophy (Book Review)" in Duke Law Journal (1989) 1752-3503.

Steven, R.B. (1983). Law school: legal education in America from the 1850s to the 1980s. Chapel Hill: The University of North Carolina Press.

Sunstein, C. (1995). "On legal theory and legal practice" in Shapiro, I. \& DeCew, J. (1995) (eds), Nomos XXXVIII: Theory and practice, New York University Press.

Thornton, M. (1996). Dissonance and distrust. women In legal profession. Oxford University Press.

Tushnet, M. (1991). "Critical legal studies: A political history" in Yale Law Journal 100(5):1515-1544.

Twining, W. (1994). "Brief history of legal education" in Blackstone's Tower: The English law school. London: Sweet and Maxwell.

Twining, W. (1997).Law in Context, Clarendon Press Oxford

Wildman, S.M. (1995). "Privilege and liberalism in legal education: Teaching and learning in a diverse environment" in Berkeley Women's Law Journal 88:88-90.

\section{Cases}

Califano v. Goldfarb (1977) 430 U. S. 199.

Califano v. Webster (1977) 430 U.S. 313.

California Federal Saving \& Loan Associati'n v. Guerra (1987) 479 U.S. 272.

Geduldig v.Aiello (1974) 417 U.S. 484

Reed v. Reed (1971) 404 U.S. 71, 76 
